\title{
Empirical analysis of the determinants of the IPCA for the period of 2000 to 2011: An approach based on a SVAR model
}

\author{
Mateus Boldrine Abrita \\ Eliane Cristina de Araújo² \\ Angelo Rondina Neto ${ }^{3}$
}

\begin{abstract}
This study examines empirically the determinants of the Brazilian inflation, measured by the Broad Consumer Price Index (IPCA) and its decomposition, estimating two equations and using an autoregressive model. The database covers the period from January 2000 to December 2011. Five main groups are mentioned as the determinants of inflation: i) Aggregate Demand; ii) Aggregate Supply; iii) Exchange Rate; iv) Salaries and v) Inertia. The evidences reveals that inertia, external factors and the supply conditions overlap the demand in the determination of the Brazilian inflation. Thus, inflation shows to be little sensitive to the level of activity.
\end{abstract}

Key-words: Inflation; IPCA; SVAR (Structural Autoregressive Vector); Brazilian economy.

JEL Classification: E44; G10; C50.

Análise empírica dos determinantes do ipca no período de 2000 até 2011: Uma abordagem com base em um modelo SVAR

Resumo: Esse estudo analisa empiricamente quais são os determinantes do IPCA (índice cheio), e suas decomposições, estimando para tal duas equações, e utilizado modelos autorregressivos vetoriais. A base de dados compreende o período de janeiro de 2000 até dezembro de 2011. Cinco principais grupos são apontados como os determinantes da inflação: i) Demanda agregada; ii) Oferta agregada; iii) Taxa de câmbio; iv) Salários e v) Inércia. As evidências revelam que a inércia, os fatores externos e as condições de oferta se sobrepõem à demanda no sentido de determinar a inflação brasileira. Assim, a inflação se mostra pouco sensível ao nível de atividade.

Palavras-chave: Inflação; IPCA; VAR estrutural; Economia brasileira.

1 Professor efetivo na Universidade Estadual de Mato Grosso do Sul (UEMS). Mestre pelo Programa de Pós-Graduação em Ciências Econômicas da Universidade Estadual de Maringá (PCE/ UEM). Bacharel em Ciências Econômicas pela UFMS. E-mail: mateusabrita@hotmail.com

2 Mestre em Economia pela Universidade Estadual de Maringá com intercâmbio na Technische universität Ilmenau (Alemanha) e Doutora em Economia pela Universidade Federal do Rio de Janeiro. Professora adjunta da Universidade Estadual de Maringá. E-mail: elianedearaujo@gmail.com

3 Professor colaborador do Departamento de Economia da Universidade Estadual de Londrina. Doutorando pelo Programa de Ciências Econômicas da Universidade Estadual de Maringá. Mestre em Economia pela Universidade Estadual de Maringá. E-mail: angelorondina@gmail.com 


\section{Introduction}

The issue of inflation is one of the most debated topics in the study of economics, especially in countries characterized by significant processes of inflationary acceleration. Thus, a better understanding of it can contribute to economics agents and policy-makers take good decisions and avoid unwanted costs and externalities that a restricted view can cause.

In many cases, monetary policy operates as a mere palliative, acting only on inflation results and ignoring the real causes of inflation. Moreover, this anti-inflationary mechanism causes serious sacrifices for society and, therefore, alternative measures of price level control are important because, once identified the real cause of inflation, measures that are more effective can be taken to circumvent it.

In recent decades, Brazil is among the world leaders in real interest rates, which creates a huge cost in terms of sacrifice for the Brazilian society. According to Giambiagi (2004), the country has allocated nearly 10\% of the Gross Domestic Product (GDP) for the payment of interest at the beginning of the decade, a reality that, unfortunately, characterized the decade of 2000 . At the same time, areas so relevant to the country such as health and education do not received the same attention.

Curiously, even with extremely high real interest rates, Brazil still has inflation rates much higher than the world average, which gives us evidence that the Inflation Targeting Regime (ITR) could not be working properly. According to Modenesi and Ferrari-Filho (2011), the monetary policy has, at its best, little efficiency to fight inflation. That is because other factors influence the level of prices that are not embedded in the foundations of the mechanisms governing the ITR.

Braga (2011) found that the component of demand was not statistically significant in the equation of goods and services and that the element of the salaries played a greater role in this regard. Araújo and Modenesi (2010) verified the importance of the external sector to the formation of the "Broad Consumer Price Index" (IPCA) in the Brazilian economy, concluding that the pass-through is significantly greater than the demand for the index explanation. Still, Pires (2008) noted that the monetary policy in Brazil does not work in its fullness given the high indexation of the public debt; therefore, the wealth effect works in reverse. Modenesi and Ferrari-Filho (2011) pointed out that the real drivers of the recent inflation in the country are structural components, related to the inertia and short-term costs, so the demand was not genuinely the main factor.

Thus, this research seeks to analyze in depth the issue of inflation in Brazil, throughout the 2000s, aiming to raise the main elements that caused and accelerated the price level, with the hypothesis that other factors such as shocks of costs, inertial component and external sector are equally, or more relevant than de demand pressures to explain the problem.

Some researches as Araújo and Modenesi (2010) and Braga (2011) sought to derive the determinants of Brazilian inflation in the recent period, through econo- 
metric models and descriptive statistics. Therefore, this paper seeks to add to the formerly, with the purpose of identifying the main causative elements if Brazilian inflation in the 2000s.

Thus, this study seeks to empirically analyze what are the determinants of the IPCA, for the full index and its decomposition between free and administered prices, estimating for such two equations to incorporate these different situations. It was adopted a database comprising the period of January 2000 to December 2011, totaling 144 observations. In general terms, five major groups are seen as the determinants of the general level of prices in Brazil: i) Aggregate Demand; ii) Aggregate Supply; iii) Exchange Rate; iv) Salaries; and v) Inertia.

The paper is divided into four parts, including the introduction and conclusion. In section two will be presented the methodology of Vector Autoregressive Models (VAR) and it addresses the data and the issue of the structural identification of the model; later, in the third will be performed Analysis and Results. Finally, section 4 presents the conclusion.

\section{Data and the identification of the structural model}

Important works addressed the vector autoregressive models (VAR), but Sims (1980) is pointed as one of the pioneers in its use. The use of VAR models gained ground in the economic studies due to its ability to analyze multiple relationships between different variables from a certain set of identification restriction. In this way, it is possible to analyze the response of the behavior of a variable when it is given a "shock" in another one - very aiding to the study of the relationships between macroeconomic variables.

According to Enders (1995), two important analyzes resulting from the VAR model are the decomposition of the variance and the impulse-response function. The decomposition of the variance show how much the chances of each variable is derived form its own variance, as well as how much it is explained by other variables in the model. The impulse-response function, otherwise, allows to observe how the variables of a particular system reacts given a "shock" in an individual variable in a time horizon, thus allowing the analysis of the relationship between different variables.

The VAR model in the reduced form presents contemporaneously correlated residuals, not allowing, therefore, the identification of independent exogenous effects on the variables. A usual way of identifying restrictions regarding the contemporary relations of the shocks is the Cholesky decomposition. However, according to Sims (1986), this approach proposes an exactly identified structure in the model, so that this analysis may provide a structure not suited to the economic realities and the causality of the data with regards to contemporary relations between the variables. 
To resolve this limitation of the Cholesky decomposition, studies as of Sims (1986), Bernanke (1986), Blanchard and Quah (1989) and Leeper, Sims and Zha (1996) presented an alternative, i.e., the use of the orthogonalization. This method allows to impose restrictions over-identified in the model, now called Structural Autoregressive Vectors (SVAR). Thus, the contemporary relations between the variables are imposed in the light of the economic theory.

In order to identify what are the determinants if the IPCA, it was used a database comprising the period of January 2000 to December 2011, totaling 144 observations. In general terms, five major groups are seen as the determinants of the general level of prices in Brazil: i) Aggregate Demand; ii) Aggregate Supply; iii) Exchange Rate; iv) Salaries; and v) Inertia.

To estimate the model, were used the variables: Broad Consumer Price Index (IPCA) of the Brazilian Institute of Geography and Statistic (IBGE); Commodities Index (comdities), elaborated by the Applied Economics Research Institute (IPEA), used as a proxy for the supply conditions as well as incorporating the prices of basic raw materials of all the economy; Index of Physical Production (quantum) of the industry (prodind) as a proxy of the aggregate demand. Minimum Wage (salminsa), provided by the IPEA and seasonally adjusted, used as a proxy for the wages; average exchange rate Real/US Dollar (cambio), provided by the Brazilian Central Bank (BCB) in order to capture the external sector; General Market Price Index (IGP_M), elaborated by the Getúlio Vargas Foundation (FGV), with the purpose of capture the inertia, because it reveals the relations of a price index on the other. In the second model, the IPCA is decomposed in Administered Prices (adm) and Free Prices (livres), in order to observe in more detail the IPCA decompositions.

The use of the variable prodind as a demand proxy brings limitations to the model, but the lack of a more broad and reliable variable for the demand conditions makes its use acceptable, considering that the level of activity reflects the behavior of the demand. According to Alencar (2006), the industrial production is cointegrated in the relation with the Gross Domestic Product (GDP), as well as they have the same stochastic trend, which can be used as proxy. Thus, the level of activity is closed linked to the demand behavior, what justifies this choice being made by a number of econometric studies. The behavior of the average worker income has a similar trajectory with the minimum salary paid in Brazil, and considering that the latter variable does not include the period analyzed, it is quite reliable the use of the minimum wage as a proxy for the income; more so, according to the Census of 2010, half of the population of Brazil lives on a minimum wage (IBGE, 2012).

To define the contemporary constrains between the variables, was observed the most evident theoretical relationships. The study was divided in two models, the first considering the variable IPCA (full index) and the second analyzing its decomposition between free and administered prices.

Thus, the benchmark of the first model follows the sequence: comdities, prodind, salminsa, cambio, igp_ $m$ and ipca. As the commodities are determined by the 
external sector, thus following a more independent path, therefore, it appears first in the ordering; however, as they are basic inputs for the whole economy, it influences all other variables in the model. The industrial production, as it reflects the activity level of the economy and the demand conditions, affects the wages and the prices, being placed secondly in the order. The salaries are influenced by the supply conditions and the level of activity, as well as they influence the exchange rate, (cambio), the IGP-M and IPCA.

In turn, the exchange rate reflects the movement of the variables: commodities, industrial production and wage, and influence directly the level of inflation. In addition, finally, the IGP-M is affected by all the other variables in the model, except the IPCA, that is influenced by it. It is also assumed the following contemporary relations: from the industrial production towards the exchange rate; from the exchange rate towards the IGP_M and IPCA; and form IGP-M towards the IPCA, as shown in the equation (1) and in the matrix $s$.

$$
i p c a=\text { comdities }+ \text { prodind }+ \text { salmins } a+\text { cambio }+i g p_{m}+i p c a
$$

$$
S=\left[\begin{array}{cccccc}
1 & 0 & 0 & 0 & 0 & 0 \\
0 & 1 & 0 & 0 & 0 & 0 \\
0 & 0 & 1 & 0 & 0 & 0 \\
0 & A_{42} & 0 & 1 & 0 & 0 \\
0 & 0 & 0 & A_{54} & 1 & 0 \\
0 & 0 & 0 & A_{64} & A_{65} & 1
\end{array}\right]
$$

For the second equation, the benchmark follows the sequence: comdities, prodind, salminsa, cambio, igp_m, livres and $a d m$, following the same reasoning of the first equation, but with the IPCA decomposed between free and administered process. Still is admitted the contemporary relations: from industrial production towards the exchange rate; from the exchange rate towards the IGP-M (with free and administered prices), from the IGP-M (with free and administered prices) and of the free to the administered prices. As it is represented in equation (2) and in the matrix $S_{1}$.

$$
\text { ipca }=\text { comdities }+ \text { prodind }+ \text { salmins } a+\text { cambio }+i g p-m+\text { livres }+a d m
$$

$$
S_{1}=\left[\begin{array}{ccccccc}
1 & 0 & 0 & 0 & 0 & 0 & 0 \\
0 & 1 & 0 & 0 & 0 & 0 & 0 \\
0 & 0 & 1 & 0 & 0 & 0 & 0 \\
0 & A_{42} & 0 & 1 & 0 & 0 & 0 \\
0 & 0 & 0 & A_{54} & 1 & 0 & 0 \\
0 & 0 & 0 & A_{64} & A_{65} & 1 & 0 \\
0 & 0 & 0 & A_{74} & A_{75} & A_{76} & 1
\end{array}\right]
$$


In the next section will be performed the unit root tests, in order to verify the presence or absence of unit root in the variables addressed in the model. This is done with the purpose of analyzing the stationarity of each series.

\section{Analysis and results}

Firstly, in order to check if the variables follow a stationary stochastic process trajectory, it was performed the Augmented Dickey-Fuller (ADF) and the Phillips-Perron (PP) unit root tests. In Table 1 is presented the ADF test results for the series in level and in the first difference, with the null hypothesis $(\mathrm{HO})$ that the series have a unit root, i.e., are not stationary.

The results indicate that the variables: $a d m$, comdities, igp_ $m$, ipca and salminsa are stationary with $5 \%$ level of statistical significance, considering that the inflation taxes already measures the growth of the price index, i.e., are in first difference. However, the variables cambio, ncomerc and prodind are not stationary in level, but are in its first difference. It is important to highlight that salminsa was stationary in $5 \%$ level, but it is interesting to work with the series in first difference in order to capture the variations of it.

Table 1: Augmented Dickey-Fuller Unit root test in level and first differences

\begin{tabular}{|c|c|c|c|c|c|c|}
\hline \multirow[t]{2}{*}{ Variable } & \multirow[t]{2}{*}{ Terms } & \multirow[t]{2}{*}{ t statistic } & \multirow[t]{2}{*}{ Prob } & \multicolumn{3}{|c|}{ Critical Values } \\
\hline & & & & $1 \%$ & $5 \%$ & $10 \%$ \\
\hline $\mathrm{adm}$ & None & -3.439676 & 0.0007 & -2.58147 & -1.94311 & -1.61521 \\
\hline cambio & $\mathrm{I}$ & -1.658077 & 0.4503 & -3.47681 & -2.88183 & -2.57767 \\
\hline comdities & $\mathrm{I}, \mathrm{T}$ & -4.488424 & 0.0022 & -4.02445 & -3.44201 & -3.14561 \\
\hline comerc & None & -3.0534 & 0.0025 & -2.58147 & -1.94311 & -1.61521 \\
\hline igp_m & None & -3.359226 & 0.0009 & -2.58123 & -1.94307 & -1.61523 \\
\hline ipca & None & -3.147756 & 0.0018 & -2.58123 & -1.94307 & -1.61523 \\
\hline livres & None & -2.754463 & 0.0061 & -2.58123 & -1.94307 & -1.61523 \\
\hline ncomerc & None & 0.012872 & 0.6851 & -2.58273 & -1.94329 & -1.6151 \\
\hline prodind & $\mathrm{I}, \mathrm{T}$ & -3.389706 & 0.0568 & -4.02398 & -3.44178 & -3.14547 \\
\hline salminsa & $\mathrm{I}, \mathrm{T}$ & -3.880751 & 0.0153 & -4.02351 & -3.44155 & -3.14534 \\
\hline dcambio & $\mathrm{I}$ & -8.406642 & 0.0000 & -3.47681 & -2.88183 & -2.57767 \\
\hline dncomerc & None & -6.098184 & 0.0000 & -2.58273 & -1.94329 & -1.6151 \\
\hline dprodind & $\mathrm{I}, \mathrm{T}$ & -10.43665 & 0.0000 & -4.02398 & -3.44178 & -3.14547 \\
\hline dsalminsa & $\mathrm{I}, \mathrm{T}$ & -3.820809 & 0.0184 & -4.0296 & -3.44449 & -3.14706 \\
\hline
\end{tabular}

Source: Authors' elaboration. 
For confirming the unit root tests presented by the ADF, Table 2 shows the results for the PP unit root test, which has the same null hypothesis of the ADF test. Thus, the analysis of the results supports, in general, the previous conclusions, indicating that adm, comerc, igp_m, ipca and livres are already stationary in level, and that cambio and prodind are not stationary in level.

Considering in the first difference, all the series are stationary. It is important to highlight that the salminsa variable has the same characteristics of the ADF test. However, the variables ncomerc and comdities gave divergent results and it was decided to use the results of the ADF against the PP. However, in general, the tests shown that most of the variables presented themselves as stationary already in level, and those that were non-stationary in level were differentiated and have become stationary.

Table 2: Phillips-Perron unit root test in level and first differences

\begin{tabular}{c|c|c|c|c|c|c}
\hline Variable & Terms & t statistic & Prob & \multicolumn{3}{|c}{ Critical Values } \\
\hline & & & & $1 \%$ & $5 \%$ & $10 \%$ \\
\hline adm & None & -6.170472 & 0.0000 & -2.58123 & -1.94311 & -1.61521 \\
\hline cambio & I & -1.656978 & 0.4509 & -3.47647 & -2.88183 & -2.57767 \\
\hline comdities & I,T & -3.08581 & 0.1137 & -4.02351 & -3.44201 & -3.14561 \\
\hline igp_m & None & -3.176185 & 0.0017 & -2.58123 & -1.94311 & -1.61521 \\
\hline ipca & None & -3.332856 & 0.001 & -2.58123 & -1.94307 & -1.61523 \\
\hline livres & None & -2.754463 & 0.0061 & -2.58123 & -1.94307 & -1.61523 \\
\hline ncomerc & None & -3.846345 & 0.0002 & -2.58123 & -1.94329 & -1.6151 \\
\hline prodind & I,T & -3.203532 & 0.0879 & -4.02351 & -3.44178 & -3.14547 \\
\hline salminsa & I,T & -3.566271 & 0.0364 & -4.02351 & -3.44155 & -3.14534 \\
\hline dcambio & I & -8.650279 & 0.0000 & -3.47681 & -2.88183 & -2.57767 \\
\hline dncomerc & None & -30.12112 & 0.0000 & -2.58135 & -1.94329 & -1.6151 \\
\hline dprodind & I,T & -10.40017 & 0.0000 & -4.02398 & -3.44178 & -3.14547 \\
\hline dsalminsa & I,T & -27.21907 & 0.0001 & -4.02398 & -3.44449 & -3.14706 \\
\hline
\end{tabular}

Source: Authors' elaboration.

Since most of the series are already stationary in level, the cointegration tests, in order to check for possible long-term relationships between the variables, are not necessary. After analyzing the stationarity of the series, Table 3 presents the optimum number of lags, i.e., how many gaps are best suited to the model. 
Abrita; Araújo; Neto - Empirical analysis of the determinants of the IPCA...

Table 3: Optimum lag number test for the model 1

\begin{tabular}{|c|c|c|c|c|c|c|}
\hline Lag & $\log L$ & LR & FPE & AIC & SC & $\mathrm{HQ}$ \\
\hline \multicolumn{7}{|c|}{ Model 1} \\
\hline 0 & -1611.225 & NA & 1024.167 & 23.95890 & 24.08802 & 24.01137 \\
\hline 1 & -1210.724 & 759.4686 & 4.628244 & 18.55888 & $19.46274 \%$ & $18.92619 *$ \\
\hline 2 & -1161.240 & 89.43802 & 3.801690 & 18.35912 & 20.03772 & 19.04125 \\
\hline 3 & -1122.763 & 66.12401 & $3.692996 \%$ & $18.32241^{*}$ & 20.77576 & 19.31938 \\
\hline 4 & -1100.230 & 36.71976 & 4.575007 & 18.52193 & 21.75002 & 19.83373 \\
\hline 5 & -1059.208 & $63.20471^{*}$ & 4.350502 & 18.44753 & 22.45035 & 20.07416 \\
\hline 6 & -1030.442 & 41.76368 & 5.021416 & 18.55470 & 23.33226 & 20.49617 \\
\hline 7 & -999.6678 & 41.94460 & 5.712177 & 18.63212 & 24.18442 & 20.88842 \\
\hline 8 & -972.9027 & 34.10074 & 7.026165 & 18.76893 & 25.09597 & 21.34006 \\
\hline \multicolumn{7}{|c|}{ Model 2} \\
\hline 0 & -1611.225 & NA & 1024.167 & 23.95890 & 24.08802 & 24.01137 \\
\hline 1 & -1210.724 & 759.4686 & 4.628244 & 18.55888 & $19.46274 \%$ & $18.92619 *$ \\
\hline 2 & -1161.240 & 89.43802 & 3.801690 & 18.35912 & 20.03772 & 19.04125 \\
\hline 3 & -1122.763 & 66.12401 & $3.692996 \%$ & $18.32241 \%$ & 20.77576 & 19.31938 \\
\hline 4 & -1100.230 & 36.71976 & 4.575007 & 18.52193 & 21.75002 & 19.83373 \\
\hline 5 & -1059.208 & $63.20471 \%$ & 4.350502 & 18.44753 & 22.45035 & 20.07416 \\
\hline 6 & -1030.442 & 41.76368 & 5.021416 & 18.55470 & 23.33226 & 20.49617 \\
\hline 7 & -999.6678 & 41.94460 & 5.712177 & 18.63212 & 24.18442 & 20.88842 \\
\hline
\end{tabular}

Source: Authors' elaboration.

The tests performed in table Table 3 indicate that the optimal number of lags which adjust the model (1) would be 1, 3 or 5 lags; however, as shown for the model (2), the optimal number of lags which best adjust the model are 1,2 or 5. Considering both models, the use of five lags shown to be the more adjusted. Thus, the next step is to analyze the model's robustness, applying the tests for heteroscedasticity, autocorrelation, normality and stability.

\subsection{Robustness Tests}

In order to confirm if the model is well specified, it is interesting to perform the heteroscedasticity and residual autocorrelation tests. Tables 4 and 5 present the autocorrelation tests. 
Table 4: Autocorrelation test for model 1

\begin{tabular}{l|l|l}
\hline 1 & 49.13835 & 0.0710 \\
\hline 2 & 45.56395 & 0.1319 \\
\hline 3 & 45.44887 & 0.1344 \\
\hline 4 & 42.28337 & 0.2180 \\
\hline 5 & 41.22602 & 0.2527 \\
\hline 1 & 49.13835 & 0.0710 \\
\hline
\end{tabular}

Source: Authors' elaboration.

Table 5: Autocorrelation test for model 2

\begin{tabular}{c|c|c}
\hline Lags & LM-Stat & Prob \\
\hline 1 & 71.34433 & 0.0202 \\
\hline 2 & 58.52805 & 0.1653 \\
\hline 3 & 64.56319 & 0.0672 \\
\hline 4 & 48.26165 & 0.5030 \\
\hline 5 & 46.53633 & 0.5736 \\
\hline
\end{tabular}

Source: Authors' elaboration.

Tables 4 and 5 reveal that there is no evidence to reject the null hypothesis of no autocorrelation. Therefore, the next step is to analyze the heteroscedasticity of the residuals, presented in tables 6 and 7 .

Table 6: Heteroscedasticity test for model 1

\begin{tabular}{c|c|c}
\hline Chi-sq & df & Prob \\
\hline 1347.241 & 1260 & 0.0434 \\
\hline
\end{tabular}

Source: Authors' elaboration.

Table 7: Heteroscedasticity test for model 2

\begin{tabular}{c|c|c}
\hline Chi-sq & df & Prob \\
\hline 2032.635 & 1960 & 0.1237 \\
\hline
\end{tabular}

Source: Authors' elaboration.

The results of tables 6 and 7 give evidence of no presence of heteroscedasticity in the residuals. Therefore, the model has suitable properties. 
A test for normality of the residuals was applied, but they have shown not to be normal. However, this problem can be reversed by simply adding more observations in the model. In that way, this does not invalidate the results since, considering the central limit theorem, asymptotically, whatever the distribution of the variable of interest for large samples, the distribution of the sample means will be approximately normally distributed and tend to present a normal distribution.

Finally, a last test was applied to verify the stability of the SVAR model, and can be observed in figure Figure 1.

Figure 1: Stability test for the SVAR1 and SVAR2
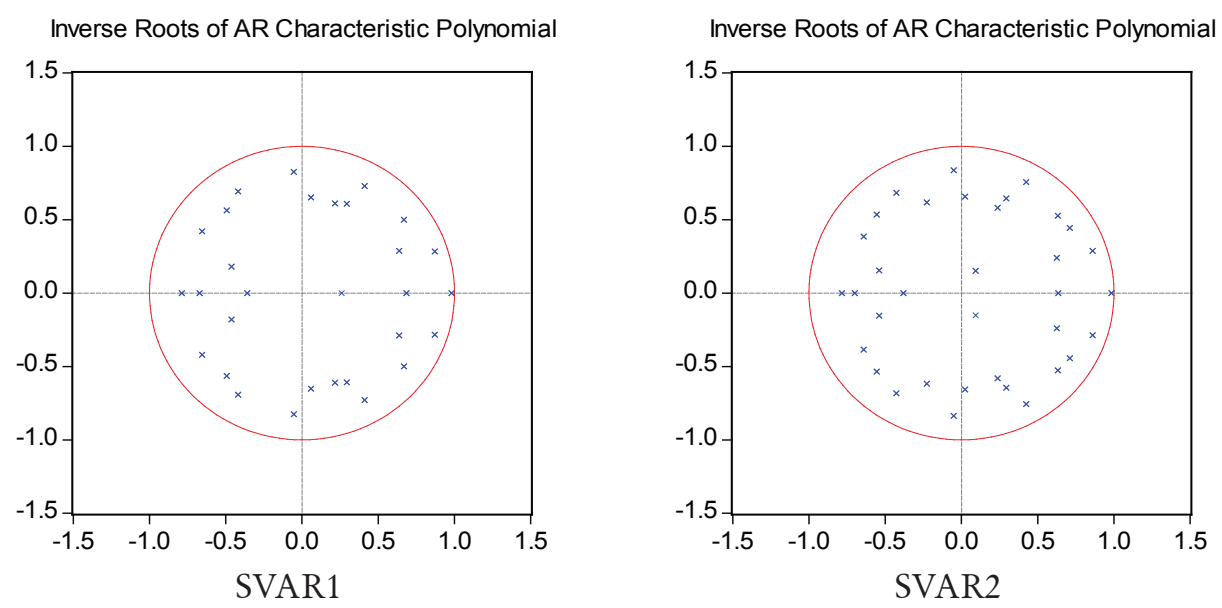

Source: Authors' elaboration.

The results of the stability tests shown in Figure 1 reveal that the models are stables. After performing the robustness tests, the next section analyzes the variance's decomposition and the impulse-response in order to check which are the determinants of IPCA in the 2000s.

\subsection{Variance decomposition analysis for the IPCA}

The analysis of the decomposition of the variance allows one to observe the relative importance of each variable in the determination of the IPCA. The ordering of the variables is structural, according to the following benchmark: comdities, proind, salminsa, cambio, igp_m and ipca.

As observed in Table 8, most of the inflation variance is explained by the variable itself, with $37,68 \%$; as the IGP-M also showed values in the order of $16,96 \%$; and the inertia shown to have a key role in explaining inflation. Another highlight is the exchange rate, with $35,55 \%$, reveling that the IPCA is strongly influenced by it. It 
should also be noted that the demand, with $0,74 \%$, presented derisive values, which shows that it is not a good proxy for the demand, but the variables for commodities and for the salaries presented higher percentages, with $6,32 \%$ and $2,73 \%$ respectively.

Thus, it is clear that the inertia, the exchange rate and the supply conditions, represented by the commodities, are the main determinants in the explanation of the behavior of the IPCA. However, demand showed no significant values, thus demonstrating that the inertial inflation, the imported inflation and the inflation of the basic supplies such as food and raw materials characterize more the Brazilian inflation than the demand inflation for the period analyzed.

Table 8: Variance's decomposition of IPCA (full index)

\begin{tabular}{c|c|c|c|c|c|c|c}
\hline Period & S.E. & comdities & prodind & salminsa & cambio & igp-m & ipca \\
\hline 1 & 8.451006 & 0.000000 & 0.034025 & 0.000000 & 6.447427 & 28.91441 & 64.60414 \\
\hline 3 & 21.39459 & 6.323873 & 0.303705 & 0.586049 & 18.02113 & 23.13884 & 51.62641 \\
\hline 5 & 33.75945 & 6.878437 & 0.336505 & 1.906237 & 28.58674 & 19.38640 & 42.90567 \\
\hline 7 & 42.29088 & 6.101007 & 0.457847 & 2.437050 & 34.93489 & 17.82496 & 38.24425 \\
\hline 10 & 49.31205 & 6.028843 & 0.722711 & 2.684612 & 35.97377 & 16.72887 & 37.86120 \\
\hline 12 & 52.77756 & 6.322291 & 0.743747 & 2.731194 & 35.55794 & 16.96130 & 37.68353 \\
\hline 1 & 8.451006 & 0.000000 & 0.034025 & 0.000000 & 6.447427 & 28.91441 & 64.60414 \\
\hline
\end{tabular}

Factorization Structural: comdities prodind salminsa cambio igp-m ipca.

Source: Authors' elaboration.

Performed the analysis of the determinants of the IPCA, considering the full index, following it is presented the decomposition of the variance addressing its breakdowns, between free and administered prices, in order to verify which variables most influence these components. The benchmark follows the sequence: comdities, prodind, salminsa, cambio, igp_m, livres and $a d m$.

Table 9 shows once again that the inertia is critical in the determination of the market prices, because the variable itself explains 35\% of the variation, added to the IGP-M, with $15,17 \%$. The exchange rate also appears prominently, featuring $32,99 \%$ of the determination, in addition to the commodities, with a share of $7,27 \%$ in the determination of the free prices. The demand, however, has much lower values, in the order of $1,33 \%$.

Therefore, the behavior of the free index is determined mainly by its own trajectory, by the exchange rate and by the IGP-M, revealing that the inertia and the external sector are fundamental to its determination. The supply conditions appear as the third important explanation albeit at a slightly lower level, and the demand also does not seem like a good proxy for the inflation considering the free prices. 
Abrita; Araújo; Neto - Empirical analysis of the determinants of the IPCA...

Table 9: Variance's decomposition of IPCA (free prices)

\begin{tabular}{c|c|c|c|c|c|c|c|c}
\hline Period & S.E. & comdities & prodind & salminsa & cambio & igp-m & livres & adm \\
\hline 1 & 8.460444 & 0.000000 & 0.011969 & 0.000000 & 3.321407 & 26.94404 & 69.72259 & $5.32 \mathrm{E}-30$ \\
\hline 3 & 21.22299 & 4.788958 & 0.584427 & 0.340376 & 11.16314 & 24.06565 & 56.97419 & 2.083265 \\
\hline 5 & 33.61978 & 8.149920 & 0.634098 & 1.442579 & 24.36874 & 18.59306 & 44.01839 & 2.793206 \\
\hline 7 & 42.41181 & 7.878065 & 0.902936 & 2.097826 & 32.11081 & 16.33263 & 37.76909 & 2.908640 \\
\hline 10 & 49.50682 & 7.302481 & 1.308277 & 2.604221 & 33.13937 & 15.04858 & 35.49817 & 5.098889 \\
\hline 12 & 52.78793 & 7.270505 & 1.330729 & 2.640171 & 32.99507 & 15.17040 & 35.07269 & 5.520434 \\
\hline
\end{tabular}

Factorization Structural: comdities prodind salminsa cambio igp-m livres adm.

Source: Authors' elaboration.

The decomposition of the variance, to check which variables explain the administered prices, is shown in Table 10, and follows the same sequence of the equation above: comdities, prodind, salminsa, cambio, igp_m, livres and $a d m$.

The analysis dry a similar logic to the other, but with different proportions, in the sense of increasing the weight for inertia and decreasing the participation of others. The regulated prices are explained by their own variations, with $66,81 \%$ in the period plus 6,84 of the IGP-M variable. The exchange rate explains $18,88 \%$ and the commodities $2,83 \%$, as the demand gives very low values, with $0,86 \%$.

It is evident that the strongest component in determining the price inflation is the inertia, i.e., inflation follows an upward trend with a certain independence of other shocks of the economy; Yet, the external sector plays an important role in its determination; however, corroborating with other analysis, the demand inflation does not characterize the behavior of administered prices in the period.

Table 10: Variance's decomposition of IPCA (administered prices)

\begin{tabular}{c|c|c|c|c|c|c|c|c}
\hline Period & S.E. & comdities & prodind & salminsa & cambio & igp-m & livres & adm \\
\hline 1 & 1.814068 & 0.000000 & 0.016454 & 0.000000 & 4.566275 & 8.764384 & 0.041531 & 86.61136 \\
\hline 3 & 2.071807 & 1.053884 & 0.032920 & 0.133173 & 13.04574 & 7.084031 & 0.260082 & 78.39017 \\
\hline 5 & 2.292072 & 1.034160 & 0.652911 & 0.424915 & 15.82178 & 6.563217 & 2.223517 & 73.27950 \\
\hline 7 & 2.403959 & 1.164349 & 0.744826 & 0.739053 & 17.81378 & 6.855849 & 2.167151 & 70.51499 \\
\hline 10 & 2.545582 & 1.590792 & 0.839157 & 0.861165 & 19.22130 & 6.726697 & 2.581636 & 68.17925 \\
\hline 12 & 2.571205 & 2.837453 & 0.869233 & 0.861358 & 18.88434 & 6.847076 & 2.888144 & 66.81239 \\
\hline
\end{tabular}

Factorization Structural: comdities prodind salminsa cambio igp-m livres adm. Source: Authors' elaboration.

After analyzing the variance's decomposition, it is clear that the inertia elements and the exchange rate play a decisive role in the explanation of the variation of inflation in Brazil in the 2000s, for both the IPCA (full index) as for its decompositions. It is also worth noting that, although to a lesser extent, the value of the commodities also played an important role in the IPCA. 
The determination of the free and administered prices follows the same logic, but with different weights. In the case of the free prices, the exchange rate plays a more important role, as the administered prices are primarily explained by its own variance, indicating a strong presence of inflationary inertia.

The next section deals with the analysis of the impulse-response functions of the IPCA, of free and administered prices, in order to see how these variables behave given a shock in the other variables.

\subsection{Impulse-response functions analysis for the IPCA}

Figure 2 shows in a clear manner that the external sector, along with the inertia variables, plays an important role in the IPCA, in the sense of presenting more intense and lasting shocks. Commodities also have a significant impact in the short term, as well as the wages, but at a lower level. It is worth noting that the demand does not seem to influence the evolution of the IPCA.

Figure 2: Response of IPCA in a shock in: Commodities (1), Demand (2), Salaries (3), Exchange Rate (4), IGP-M (5) and IPCA (6).

Response to Structural One S.D. Innovations \pm 2 S.E.
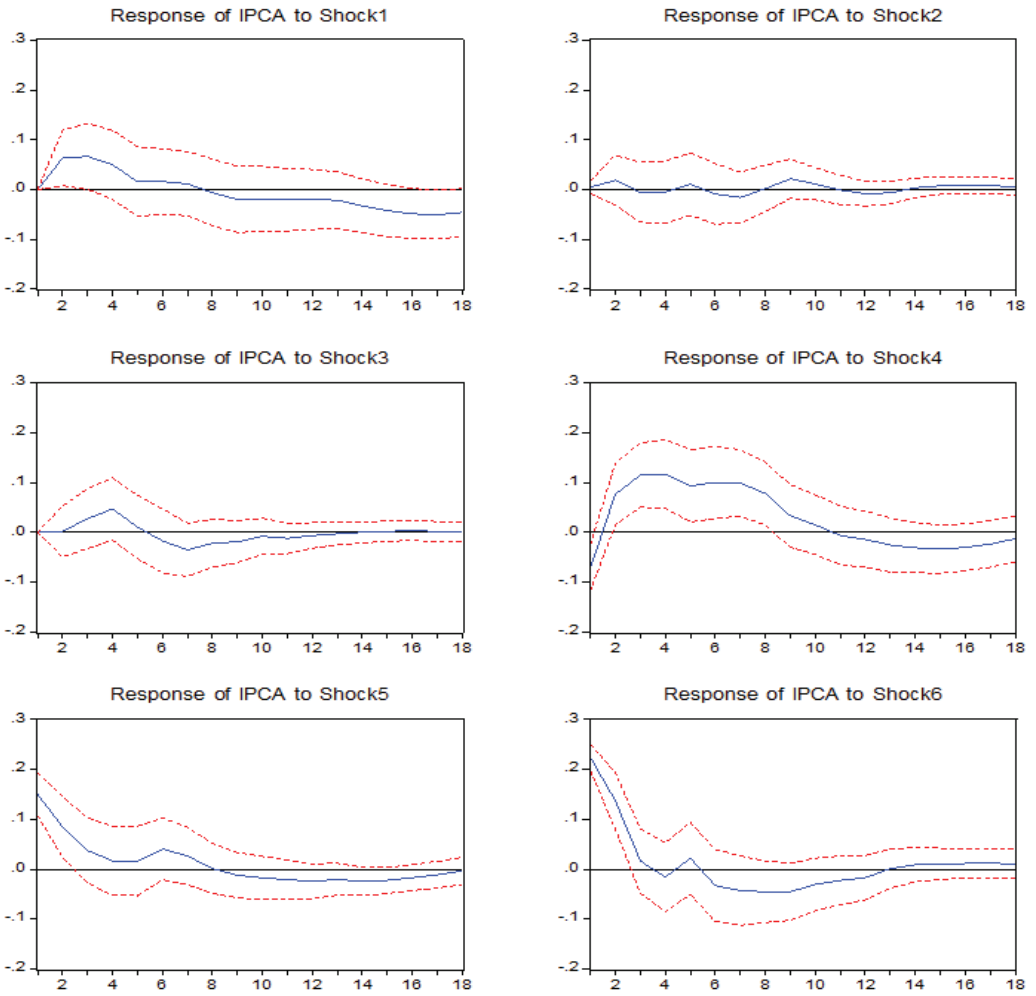

Source: Authors' elaboration. 
These relations are better evidenced in Figure 3, as it presents the shocks in an accumulated way, what facilitates the visualization.

Figure 3: Accumulated response of IPCA in a shock in: Commodities (1), Demand (2), Salaries (3), Exchange Rate (4), IGP-M (5) and IPCA (6).

Accumulated Response to Structural One S.D. Innovations \pm 2 S.E.
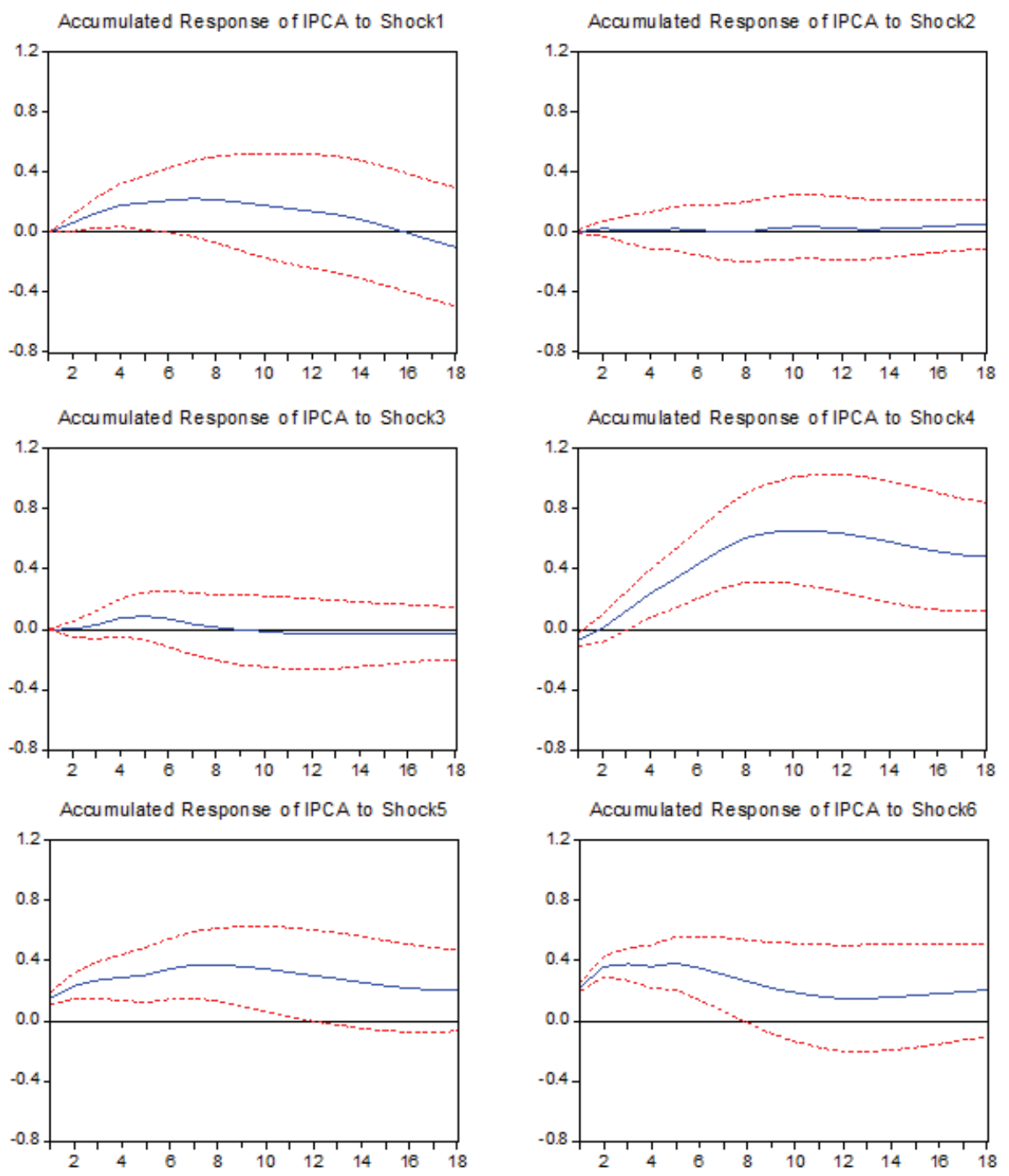

Source: Authors' elaboration.

Figure 3 corroborates with the other analysis presented, in the sense that it shows that the elements of inertia and the exchange rates are more significant in 
the evolution of the IPCA. However, it is more evident in Figure 3, that in the Figure 2, the important role that the evolution of the commodities exert, since the salaries seem to have a smaller influence than was shown in the previous figure. Again, demand has little to no influence on the evolution of the IPCA.

\subsection{Impulse-response functions analysis for the IPCA (free prices)}

With the examination of the response of free prices given a shock in the other variable, it is observed in Figure 4 that the commodities alongside with the exchange rate are responsible for much of the evolution of the free prices. In addition, the elements of inertia also are significantly present.

Figure 4: Response of IPCA (free prices) in a shock in: Commodities (1), Demand (2), Salaries (3), Exchange Rate (4), IGP-M (5) and Free (6) and Administered (7) Prices.

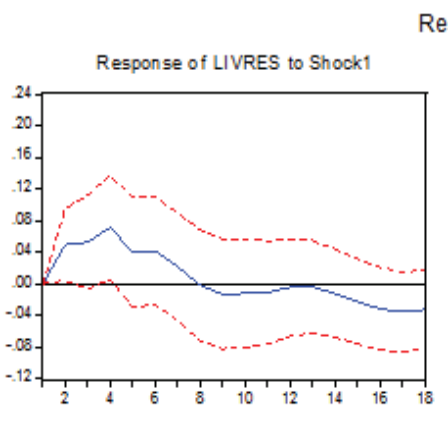

Response to Structural One S.D. Innovations \pm 2 S.E.
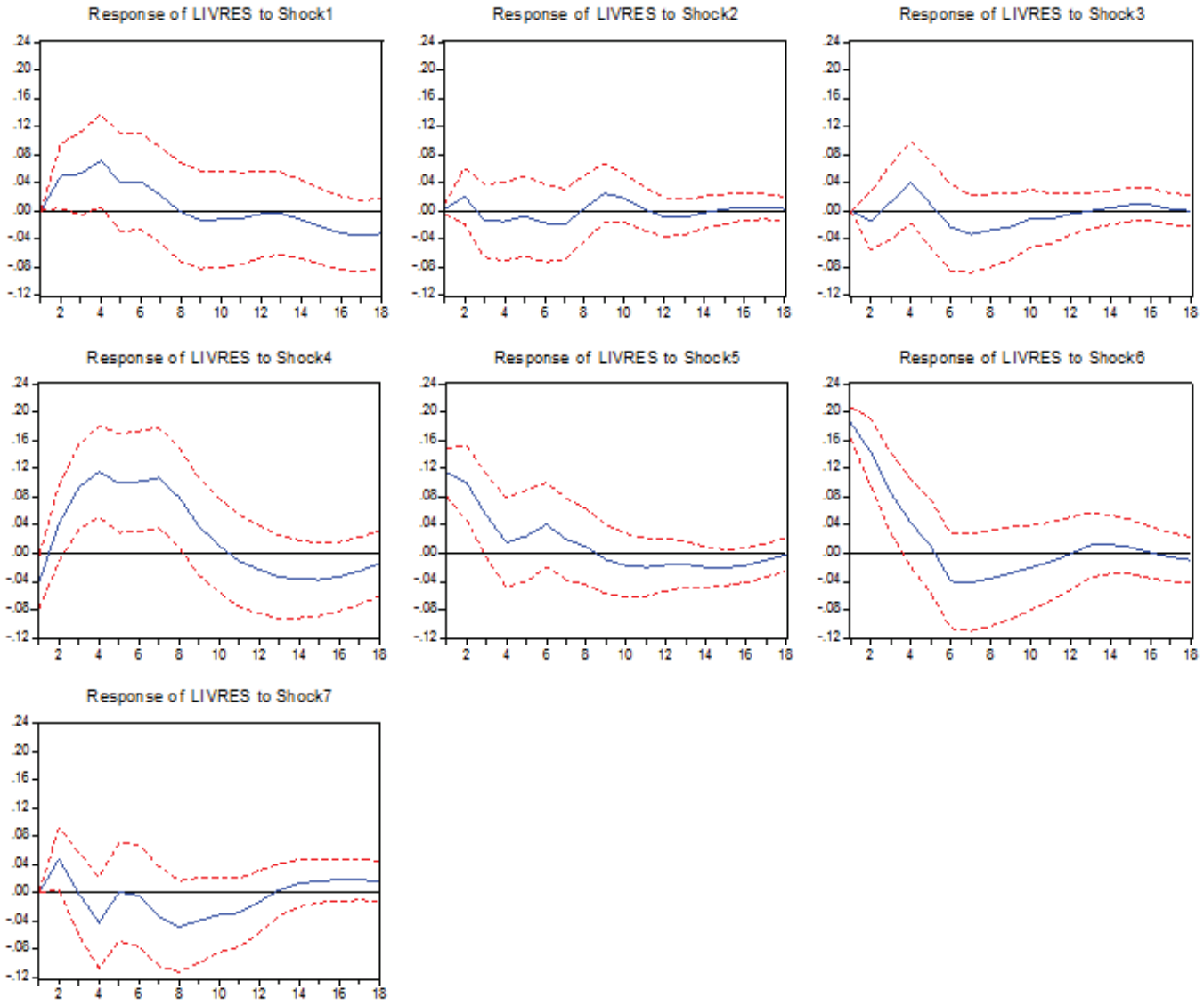

Source: Authors’ elaboration. 
Figure 5 shows the response of the free prices to the cumulatively shocks of other variables, reveling that the exchange rate, the commodities and the inertia (represented by the variable itself along with the IGP-M) are key elements to explain the evolution of the free prices. It may also be noted that the salaries and the demand have little to no influence.

Figure 5: Accumulated response of IPCA (free prices) in a shock in:

Commodities (1), Demand, Salaries, Exchange Rate, IGP-M and

Free and Administered Prices.

Accumulated Response to Structural One S.D. Innovations \pm 2 S.E.

Accumulated Response of LIVRES to Shock1

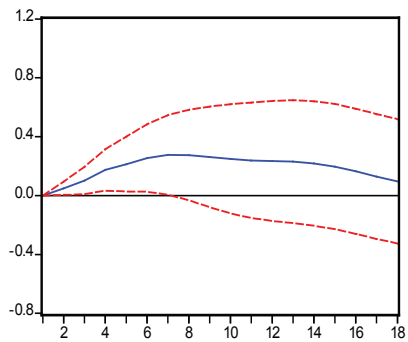

Accumulated Response of LIVRES to Shock4

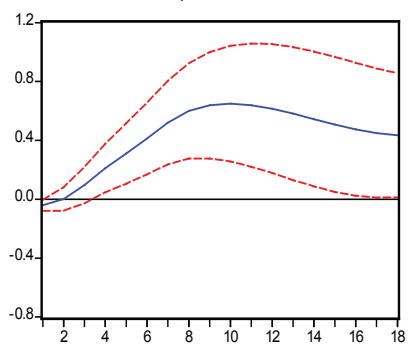

Accumulated Response of LIVRES to Shock7

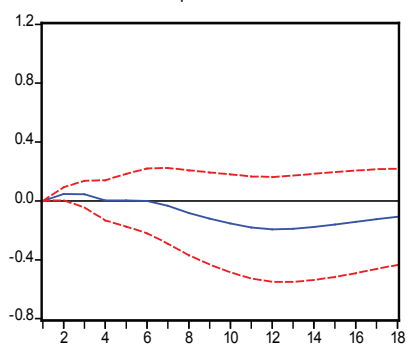

Accumulated Response of LIVRES to Shock2

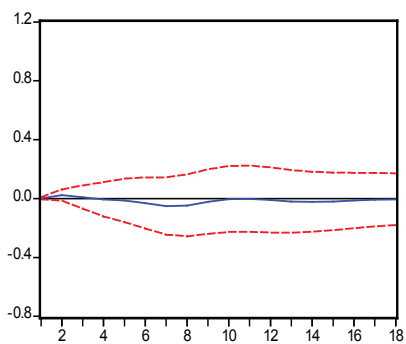

Accumulated Response of LIVRES to Shock5

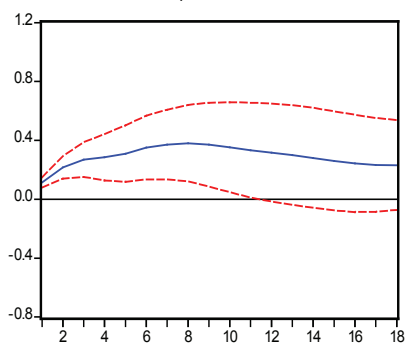

Accumulated Response of LIVRES to Shock3

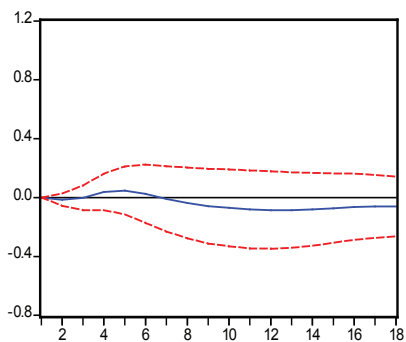

Accumulated Response of LIVRES to Shock6

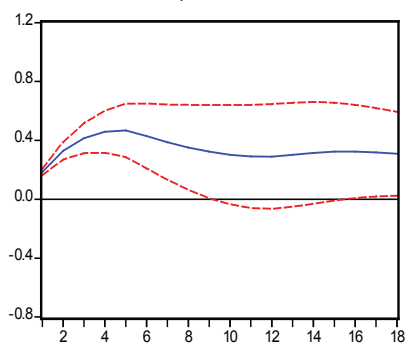

Source: Authors' elaboration.

In the next section will be presented the analysis of the impulse-response for the administered prices. 


\subsection{Impulse-response functions analysis for the IPCA (administered prices)}

By analyzing the response of administered prices given a shock in the other variables, presented in the Figure 6, it is shown that the evolution of these prices is poorly explained by variables other than itself, indicating a very sheer inertia. However, the variable exchange rate also influences its evolution, although to a lesser extent than verified for the free prices.

Figure 6: Response of IPCA (administered prices) in a shock in: Commodities

(1), Demand (2), Salaries (3), Exchange Rate (4), IGP-M (5) and Free (6) and Administered (7) Prices.

Response to Structural One S.D. Innovations \pm 2 S.E.
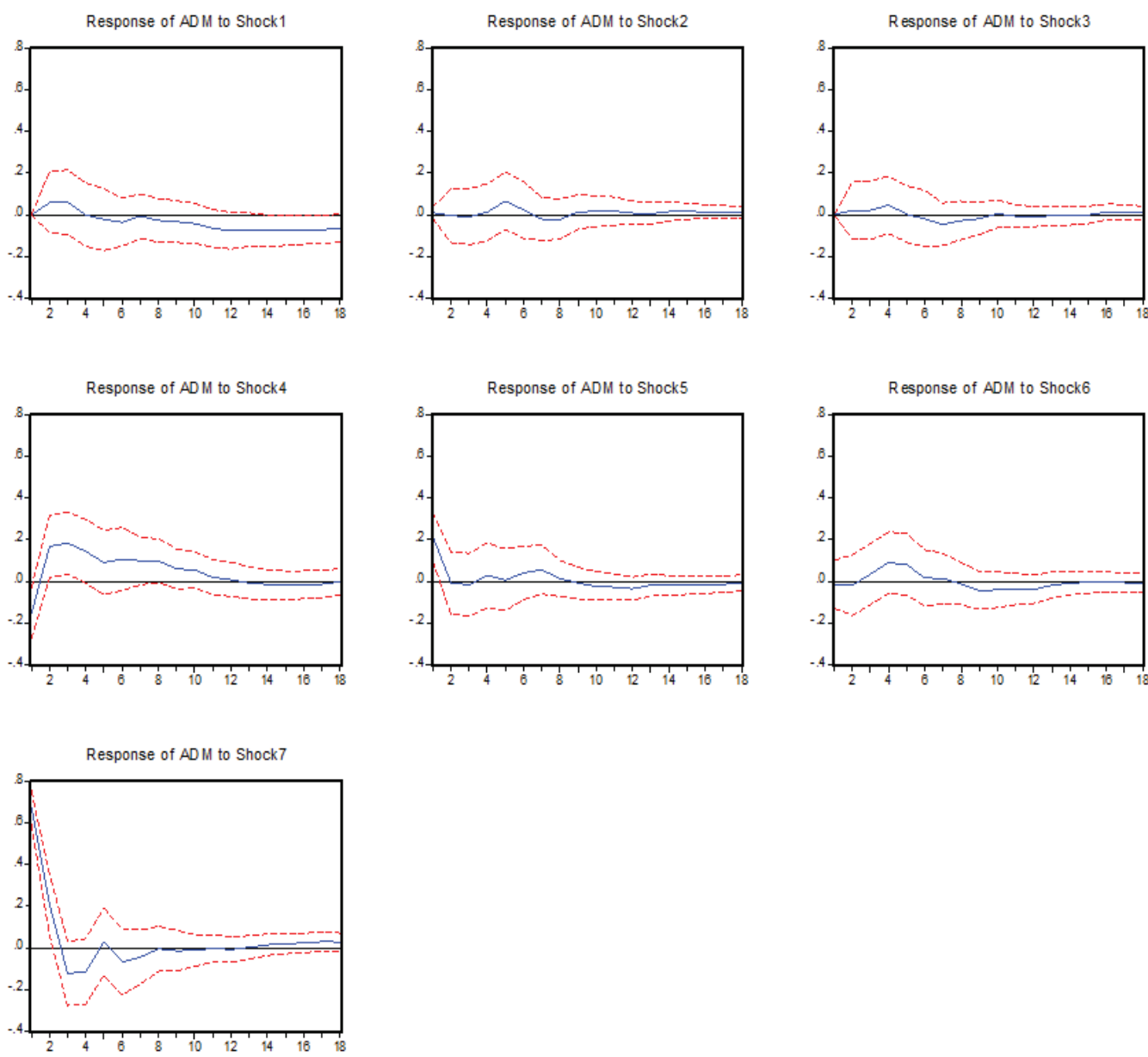

Source: Authors' elaboration. 
The Figure 7 presents the accumulated response of the shocks, what facilitates the visualization.

Figure 7: Accumulated response of IPCA (administered prices) in a shock in: Commodities (1), Demand (2), Salaries (3), Exchange Rate (4), IGP-M (5) and Free (6) and Administered (7) Prices.

Accumulated Response to Structural One S.D. Innovations \pm 2 S.E.
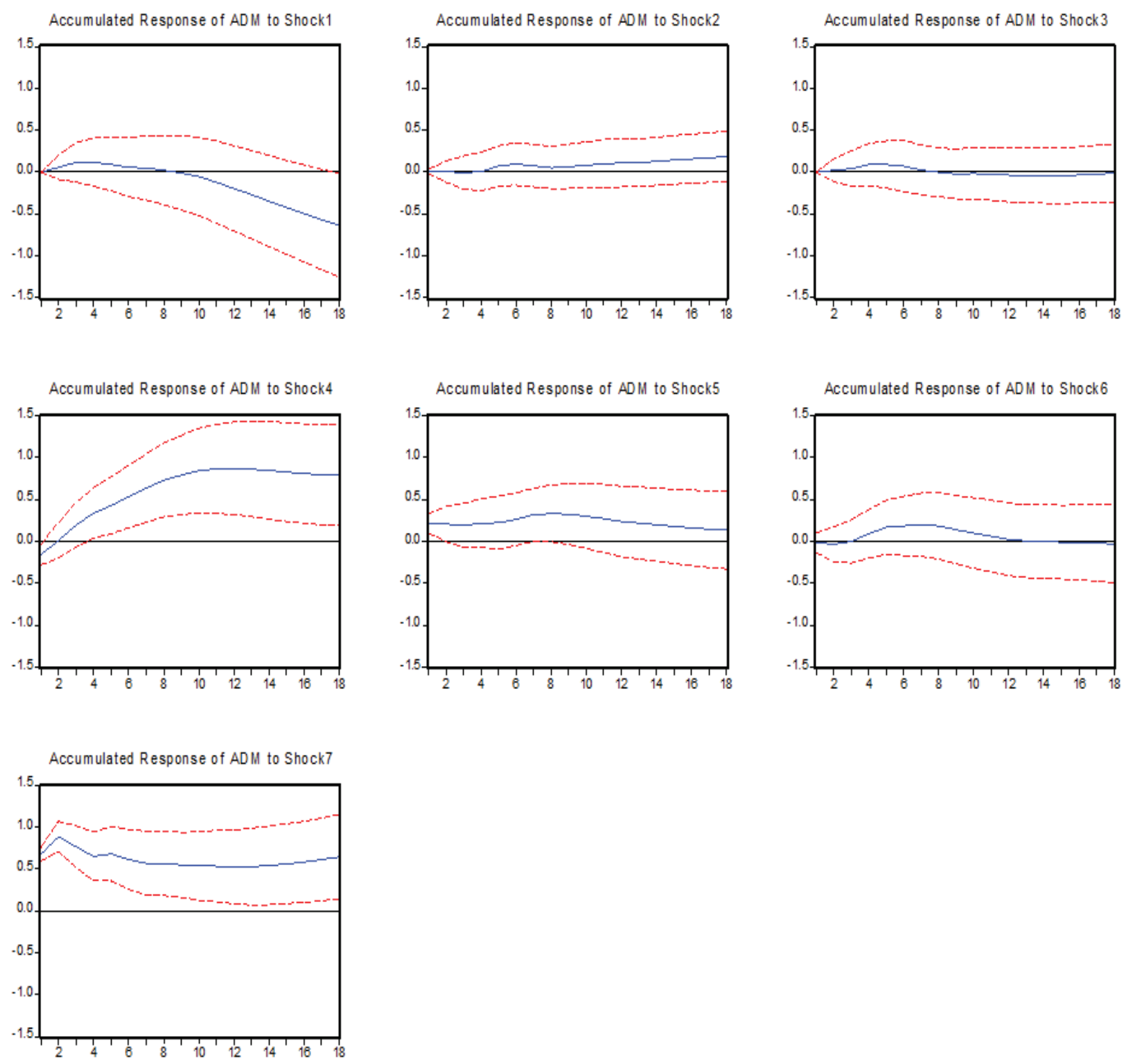

Source: Authors' elaboration.

In the analysis of the accumulated responses, seen in the Figure 7, the role of inertia and the exchange rate are more significant when compared with the other variables, which seems to have a small to almost zero influence in the evolution of the administered prices. 


\section{Conclusion}

This research sought to analyze in depth the inflation problem in Brazil, throughout the 2000s, with the objective of raising the main elements that caused and accelerated the price level in the period. The hypothesis of the research is that the other factors, such as the shocks on costs, the inertial component and the external sector are equally or more relevant than the demand pressures to explain the problem.

The econometric approach developed in this paper corroborates with the conclusion, which verified that the Brazilian inflation has been significantly pressured by the administered and the food prices, not characterizing in this way a typical demand inflation.

By analyzing the decomposition of the variance, with the purpose of verifying the main determinants of the variation of the IPCA, of the free and administered prices, it was observed that the IPCA is determined fundamentally by its own variance, as well as by the exchange rate and, to a lesser level, but significant, by the price of the commodities.

The free prices follows the same logic in the full index, with a significant weight of inertia, the exchange rate and commodities. The administered prices are explained by its own variation on a very high level, indicating that inertia is a key component to explain the trajectory of this variable and, thus, that the inertial inflation becomes relevant in the characterization of the Brazilian inflation.

The impulse-response analysis for the IPCA, for the free and administered prices, in general revealed that the responses were more intense and lasting to shocks resulting from the variable itself, from the exchange rate and the commodities. In the analysis of the cumulative response, these relationships are evident. As to the free prices, it follows the same logic as for the full index. For the administered prices, as well as the important contribution from the exchange rate, the variable itself is essential to explain its evolution.

In conclusion, the evidence presented in this paper show that inertia, external factors and the supply conditions overlap the demand in order to determine the Brazilian inflation. Thus, inflation shows little sensitive to the level of activity; and to the policies based exclusively on demand inflation may present itself inefficient and ineffective if compared to alternative measures, which are not strictly related to controlling the short term interest rate.

\section{Referências}

ALENCAR, B. "Modelos de Previsão da Inflação: Uma Análise comparativa no curto prazo”. Dissertação de mestrado profissionalizante em economia do IBMEC. 2006.

ARAÚJO, E.; MODENESI, A. A Importância do Setor Externo na Evolução do IPCA (1999-2010): uma análise com base em um modelo SVAR. XXXVIII Encontro Nacional de Economia. Salvador, dezembro, 2010. 
BERNANKE, B. Alternative explanations of the money-income correlation. Carnegie- Rochester Conference Series on Public Policy, v. 25, p. 49-100. 1986. crossref https://doi.org/10.1016/0167-2231(86)90037-0

BLANCHARD, O. J.; QUAH, D, The dynamic effects of aggregate demand and supply disturbances. American Economic Review, v. 79, p. 655-673. 1989.

BRAGA, J. A inflação brasileira na década de 2000 e a importância de políticas não monetárias de controle. <http://www.ipea.gov.br/sites/000/2/publicacoes/tds/td_ 1672. pdf $>$, último acesso dia 11/01/2011.

ENDERS, W. Applied Econometric Time Series, 1a Ed., John Wiley \& Sons, 1995.

GIAMBIAGI, F. A política fiscal do governo Lula em perspectiva histórica: Qual é o limite para o aumento do gasto público? Planejamento e políticas públicas, n. 27, jun./dez. 2004

IBGE (2012) Instituto brasileiro de geografia e estatística. Censo 2010 disponível em: <http://www.ibge.gov.br/home/estatistica/populacao/censo2010/rendimentos_preliminares/rendimentos_preliminares_tab_pdf.shtm>.

LEEPER, E., SIMS, C., ZHA, T., What does monetary policy do?. Brookings Papers on Economic Activity, n. 2, p. 1-63. 1996. crossref https://doi.org/ 10.2307/2534619

MODENESI, A.; FERRARI-FILHO, F. Choque de oferta, indexação e política monetária: breves considerações sobre a aceleração inflacionária recente. Economina \& Tecnologia, Ano 07, vol.26-Julho/Setembro de 2011.

PIRES, M. A dívida pública e a eficácia da política monetária no Brasil, 2008. Disponível em: <http://www.tesouro.fazenda.gov.br/premio_TN/XIIIpremio/ divida/ MHafdpXIIIPTN/A_Divida_publica_Eficacia_Politica_Monetario_Brasil.pdf $>$. Último acesso em 19 de janeiro de 2012.

SIMS, C., Are forecasting models usable for policy analysis? Federal Reserve Bank of Minneapolis Quarterly Review, Winter, p. 1-16. 1986. SIMS, C. Macroeconomics and reality, Econometrica, v.48, 1980.

Recebido em 27.05.16

Aprovado em 05.05.17 